\title{
FIELD STUDIES ON PARASITIC DISEASES CAUSED BY ENCYSTED METACERCARIAE AMONG SOME WILD AND CULTURED FRESHWATER FISHES
}

\author{
Elsga, I. A. M.; Badran, A. F.; Mona Abd El-Wahab* and Walaa El-Shaer* \\ Deplof FIsh Distadses and Management. Fac of Vet. Med. Suez Canal Univ. \\ -Ausinal Headth Regearch Institute. Ismalla branch.
}

\begin{abstract}
A total number of 275 freshwater fish 1100 of Clarias garlepinus. 100 of wild Oreochromis niloticus and 75 of cultured 0 . niloticus) were ranctoming collected aliue from Nite branches and a private $\Omega$ sh farm in Isrilailia governorate. The fishes were investigated for encysted metacencariae. There were no pathognomanic clinical signs or abnormalitles on the external body surface. The isotaled encysted melacercantae are iden Hfied as Cynadiplostomatid, Heterophid. Prohemistomatid. Euclinostomumand Clinostomum metacencariae. The results revealed total prevalence of 50,47 and 13.396 in C. garieptrus, wild O.niloticus and cultured O.riloticus respecthely. Such metecercaricue prevalled in spring in wild o.niloticus and C.garteptums whlle cultured o.niboticus prevailed in summer. The site specifkity showed high prevalence fo musculature of $\mathrm{C}$. gariepinus. in kidney of wild onilolicus and in spleen of cullured O.ntloticus. In addition, it is revealed that the prevalence in both males and females are

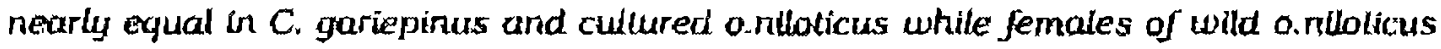
ase thighly prevaited than males.
\end{abstract}

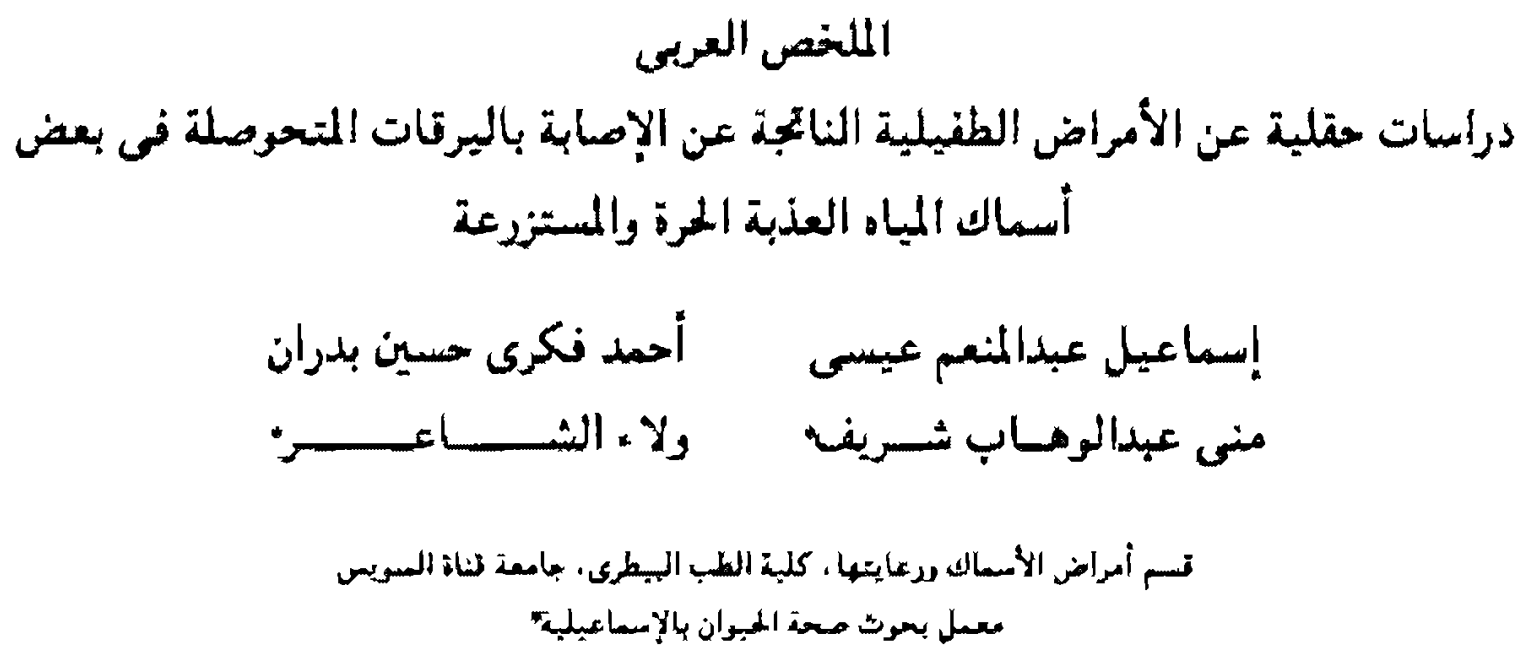

Mantoura, Vet, Hed. J. (29-38)

Vol. X. No, 1, 2008 


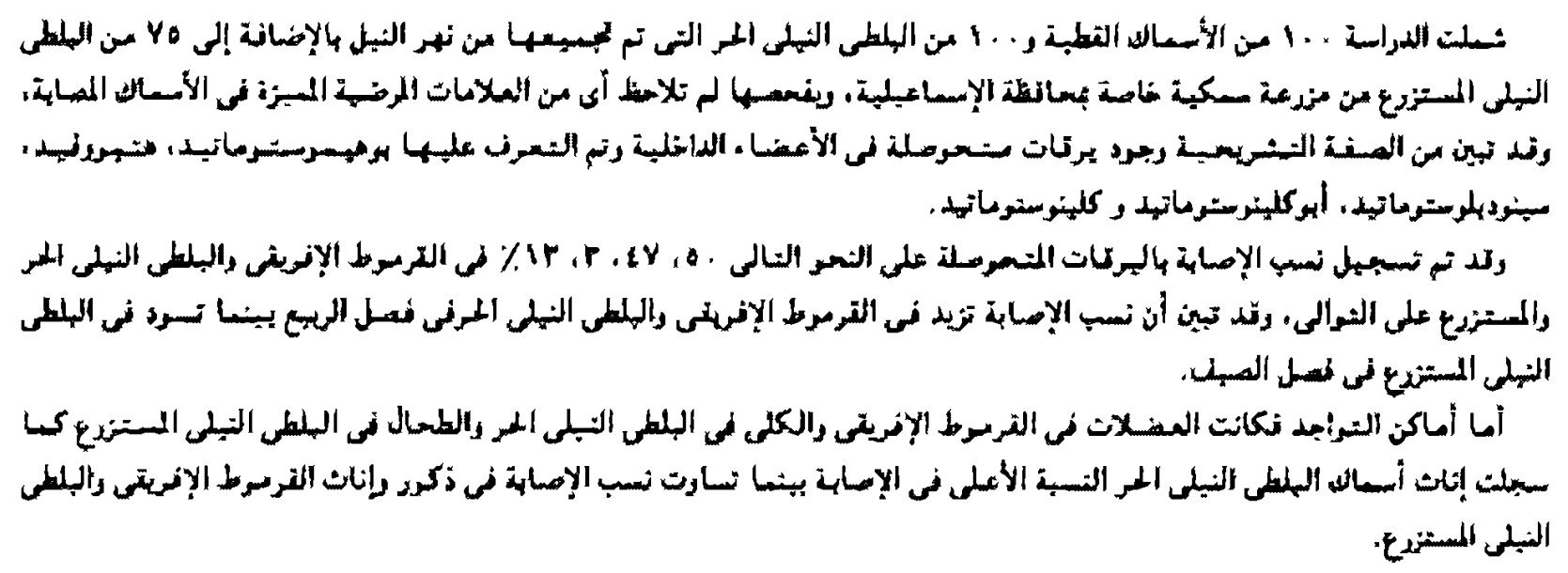

\section{INTRODUCTION}

The presence of encysted or excysted nuetacencariae are very common espectally in freshwater fishes as that may cause public healuh importance when infested ish eaten with Insuffictent cooking or light salting (Elsan, 2002).

Alsa. It leads to great economic losses wa decreasing body gain as well as they lead to fish immeraketable for human consumption (Elasa, 2002, Floyd, 2003i and Samaha, 2004).

Duffercnt data dealing with such infections In various areas and fishes rere recorded (Bhaapan 1997, Mathor E1-Amle. 2001. Balath of al., 2008 and Sawan Elahoshnegul et al., 2006) .

The present study was planned to investgate the problems in some cultured and wild freshwater flshes IClarlas garlepinus and Oreochromls nllotlcus) assoclated with the most prevaillng encysted metacercarlac regarding season, sex and site spectflaty tn sueh fishes.

\section{MATERIAL AND METHODS}

Fith:

A total number of 275 af freshwater fishes of dilTercnt body welghts were represented as 100 Clarlas garteplnus. 100 whld Oreochrouns ntloulcus and 75 eultured $O$. nlloticus were collected randomly in different seasons. The collectcd Ifshes were transported alive to the Fish Diseases Laboratory. Faculty of Vetertnary Medicine, Suez Canal University.

\section{Clinlcul pleture and grose examination}

The clinical examination of examined lishes was performed according to the methods adopted by Conroy and Eermann (1981) for deteetung abnormallues or presence of any cysts extcrnally. The abdominal wall af examIned fish was removed; the tnternal organs and musculature were exposed and examined maeroscoplcally for any gross abnormalitles.

\section{Parasitological examinntlon}

\section{A - Milcroscoplcal examination:}

The microseopical cxamination was carted out using the compression technique according to Morlohita et al. (1966) for the detec- 
Uon of encysted metacercarlae (EMC) which may lodged in/or attaehed on different organs and ussues of the examined inshes.

\section{B- Firation, stalning and monnting of the EMC:}

The procedures were done aceording to the techntques deserybed by Rruse and Pltchard, (1882). It was carrted out by keping the EMC belween two slldes. By genile pressure. llicy were fixed in small vhals containing (1096) formalln or AFA (alcohol formaline acetle acid). left ovenight then washed with tap water to get nd traces of formalin solution and stalned with alum carmine stain (Lucky, 1977) and Serniction's acetocarmine staln (Kruse and Fitchard. 1982). They were debydrated using assending grades of ethyl alcohol which were changed several times to insure dehydration and eleared in clove oil. The spectmens were mounted in Canada baisam and lent to dry in a hot alr oven at suitable temperature $\left(40^{\circ} \mathrm{C}\right)$ and covered with a cover silde. Identification of the revealed EMC is carried out acconding to Yamagotl (1988).

\section{RESULTS}

\section{Clinical Examination:}

There were no pathognomonic clinical stgns or abnormalitics on the external body ourface of the examined flshes except silght curvature anomaly and abdominal buiging in wild O. nulloticus.

\section{Postmortern examination:}

In some cases or $O$. nlloticus and most cases of $\mathrm{C}$. garieplnus. there were white or whitish cysts like nodules varying in size from pin head to pea stze were found on gllls, heart. llver, spleen. kldneys. Intestinal wall. ovary. testls. braln and musculature (Fig. 1.2).

\section{Parasltological Examlnatlon:}

The isolated EMC were differentiated into spherical or subsphencal In shape, double walled cyst. The outer wall was fraglle and casily nuptured but the Jnner one was difleult to reinove willout injurng the BMC. The whole eyst measured $0.24-0.29$ Imean 0.26 mim) lenght. $0.17-0.23$ (mcan $0.20 \mathrm{muml}$ wider. They had well developed suckers. The oral sucker was subterininal. It was identufed as Prohemlstomatd (plate 1. A). Another EMC was spherical encircled by Lwo thin layers. The ventral sucker was larger than oral one. The characterisuc features were fune streaks of black coloration (melanin pigment) in the infested musculature. It was Identlfied as Heterophtd (platc 1. BI. Also, EMC revealed cyst wall has two layers where the outer one was thick and the inner was thin and hyalme. Oral and ventral suckers were well developed and nearly equal in stze. Intestunal caeca extended nearly to postertor extremily, gonads are easily scen In posterior fourth of the nretaecrearlis body together with the excretory vesIcle and excretory pore. It was kdenuliced as Cyanodiplostomatld (plate 1.C). Large metacercartac wcre graylah white peas in the thssue of the kidneys, It was leaf shaped and falrly large. it measured 5 to $16 \mathrm{~mm}$ in length and 1.5 to $5 \mathrm{~mm}$ in widh. The ventral sucker was very large fabout 5 umes of the oral sucker) with a short esophagus has thlck inuscular bulb like. The Intestinal caeca were largely swollen In their anterfor parts. In further course tbey were narrow and very irregular in oudine (12 and 15 long branches) with dark pigmentalion. The two tegtes were situated In 
the postertor thitd of the body and the ovary was round. small and located between the testes. It was identined as Euclinostomatid (plate 1.D). Another EMC charactertzed by yellow to orange color, spherical in shape whith the cyst wall very thick. It was elongated and large measuring 02.0-02.20 (mean 02.10 mml in length and $0.32-0.52$ (mean $0.42 \mathrm{~mm}$ ) In width. The suckers were well developed. The oral sucker present subterminally and the ventral sucker was large. spherical in shape. Ceaea were very long and extended to the posterior end. The genitalia were Ill developed. It was idenunted as Clinostomatid Iplate I.E).

Total and aeasonal prevalence: The highest prevalence was found in $C$. garteplnus (50\%). Followed by wild Oreochromis niloulus $(47 \%)$. then cultured O.nllaticus (13.30\%). Also. the results revealed that EMC prevalled in spring in wild $O$.niloticus and C.garteplnus while in cultured O.niloticus prevalled in summer. Table, 1. The site specinclty showed high prevalence in musculature $1 C$. garteplnus) in kidneys (wild o.nllottcus) and in spleen (cultured O.nllotieus), Table, 2, in addition, It is revealed that the provalence in both males and fernales are nearly equal in $\mathrm{C}$. gariepinus and cultured o.niloticus while lemales of wild 0 .nllotlcus were highty prevalled than nales, Table. 3.

\section{DISCUSSION}

The current etudy revealed that in Ish metacrcartosis. there are no characteristlc cllnical signs or abnormalltes on the extemal body surface. These results support the findings of elesere (2002) who rexded that there no pathognomontc signs in the internal parastic diseases. The postmortem indings were mantrested as emaciation, paleness or hemorrhaglc. In some cases. there were enlargement of llver, gall bladder. spleen, and khdneys. In some cases of $0 . n 1$ loticus and most eases of C.garlepinus there were whlte or whltish cysts Ilke nodules varying in stze from pin head to pea slze varying in locations, on most of the internal argans and musculature. These findlings are nearly similar to the results given by Woo (1995), Rawia Adway (2000). Elssa et al. (2001), Basalony (2002) and Caman (2001).

Based on the morphologlcal and parastological examinatlons, the isolated exicysted metacercarlae from the examined flshes are Identufled as cyrrodiplostomatrd, Heterophisd. Prohemistomatld, Euclinostomum, and Cllnostomum. These results agrecd with the descriptions given by Yamagute (1988). Eiese et al. (1996), Shappan (1097), Maather El Lamie (2001) and Noor El-Doen (2008).

In the present investigation. the highest total prevalence was found in C. garlepinus followed by wild and cultured 0 . nlloticus as 50 . 47 and $13.3 \%$ respectrvely. These nearty agreed with Amany Abbase (1997) and Mather Li Lamle (2001). These Inding may be attributed to that botk C. garlepinus and wild $O$. nilotlcus live in a media rich in aquatic snalls in nature where such snalls nearly rare in $O$. nlloticus cultured in nsh farms.

Regarding the seagonal varlatlon, it is revealed that EMC prevalled in spring ill wild 
O.nlloticus and C.garlepinus whlle cultured O.niloticus prevalled in sumuner and the lowest in winter. These results nearly agreed with shaupen (1897) and Tagreed Ibrahlm (2000) who found that the highest prevalence was in ournner and the lowest in winter. These findings may be attributed to the water temperature whleh plays an important role in prevalenee. The site apecinctty showed Inigh prevalence in musculature (C. garlepinus), in kidney (wild a.nlloticus) and in spleen icul. tured $O$.niloucus). These results anong C.garlepinus agreed wh olfat Mahdy (1901): Tagreed torahim (2000) and Mather E1 Lamie (2001) who found that the Mghest prevalence In C.garleplunus was III musculature. However, our results disagreed with those given to $D$. nlloticus by oifat
Mahdy (1991); who found that the highest prevalence was in musculature. Taghreed ibrathim (2000) and Maather E1 [amle (2001) who found that the highest prevalence was in gllis.

Coneerning the prevalence in relation to sex, only females were highly infected than males in whld Oniloticus, while both sexes were equally prevalled in both eultured O.nllotieus and $C$. garteplnus. Thls may be attributed to the spawning perlod of wild 0 . ni* lotseus where they are slow. weak and eastity exposed to cercartal attack. On the other side. these results disagneed with Eiose and Haln (1993) who lound that the males were higher than females in case of yellow grub discase in tlaplas. 
Table (1): Tutal and seasonal preralence of EMC in the cxamined fislies.

\begin{tabular}{|c|c|c|c|c|c|c|c|c|c|}
\hline \multirow{2}{*}{ Seasuns } & \multicolumn{3}{|c|}{ C. guriepinus } & \multicolumn{3}{c|}{ Wild 0. miloticus } & \multicolumn{3}{c|}{ Cultured O. niloticus } \\
\cline { 2 - 10 } & 4 & $b$ & $\%$ & & $b$ & $\%$ & $a$ & $b$ & $\%$ \\
\hline Spring & 25 & 16 & 64.00 & 25 & 18 & 72.00 & 25 & 1 & 4.00 \\
\hline Summer & 25 & 11 & 44.00 & 25 & 14 & 56.00 & 25 & 8 & 32.00 \\
\hline Autumn & 25 & 12 & 48.00 & 25 & 9 & 36.00 & 25 & 1 & 4.00 \\
\hline Wintor & 25 & 11 & 44.00 & 25 & 6 & 24.00 & - & - & - \\
\hline Total & 100 & 50 & 50.00 & 100 & 47 & 47.00 & 75 & 10 & 13.30 \\
\hline
\end{tabular}

a: No. of examincel fish

b: No, of isfested fish

Table (2): Comparative prevalence of E.M.C. among different infested organs in infested fishes.

\begin{tabular}{|c|c|c|c|c|c|c|}
\hline \multirow{2}{*}{$\begin{array}{c}\text { Organs } \\
\text { Musculature }\end{array}$} & \multicolumn{2}{|c|}{$\begin{array}{l}\text { C. garlepinus } \\
\text { No. } \%\end{array}$} & \multicolumn{2}{|c|}{$\begin{array}{c}\text { Wild } \\
\text { O. niloticas } \\
\text { No. \& \% }\end{array}$} & \multicolumn{2}{|c|}{$\begin{array}{l}\text { Cultured } \\
0 . \text { nilotlcus } \\
\text { No. \& \% }\end{array}$} \\
\hline & 44 & $(88.0)$ & 17 & $(35.42)$ & 1 & $(10.0)$ \\
\hline Liver & 18 & $(36.0)$ & 22 & $(45.83)$ & 3 & $(30.0)$ \\
\hline Kidneys & 9 & (15.0) & 28 & (58.33) & 3 & $(30.0)$ \\
\hline Heart & 13 & $(26.0)$ & 13 & $(27.80)$ & & . \\
\hline Gills & 5 & $(10.0)$ & 20 & $(41.0)$ & & : \\
\hline Spleen & 5 & $(10.0)$ & 25 & $(52.0)$ & 6 & $(60.0)$ \\
\hline Testis & 3 & $(06.0)$ & & & & - \\
\hline Ovary & & $(02.0)$ & 2 & $(04.10)$ & & 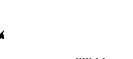 \\
\hline Brain & & . & 15 & $(31.0)$ & & * \\
\hline
\end{tabular}


Table (3): Prevalence of EMC in the examined fish in relation to sex.

\begin{tabular}{|c|c|c|c|c|c|c|c|c|c|c|c|c|c|c|c|c|c|c|}
\hline & \multicolumn{6}{|c|}{ Clariax garlepinus } & \multicolumn{6}{|c|}{ Wild 0. muaticus } & \multicolumn{6}{|c|}{ Cultured 0. mllaticus } \\
\hline & \multicolumn{3}{|c|}{$\delta$} & \multicolumn{3}{|c|}{$Q$} & \multicolumn{3}{|c|}{$\delta$} & \multicolumn{3}{|c|}{ Q } & \multicolumn{3}{|c|}{$\delta$} & \multicolumn{3}{|c|}{+} \\
\hline & $\mathbf{8}$ & b & $\%$ & $\mathbf{a}$ & b & $\%$ & $\mathbf{a}$ & b & $\%$ & $a$ & $b$ & $m / m$ & a & b & $\%$ & 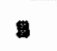 & $\mathbf{b}$ & $\%$ \\
\hline Spring & 20 & 12 & 60.00 & $\mathbf{s}$ & 4 & 80.00 & 16 & 10 & 62.50 & 9 & 8 & 88.77 & 11 & 1 & 09.10 & 14 & - & - \\
\hline Summer & 16 & 7 & 43.75 & 9 & 4 & $\$ 4.44$ & 16 & 7 & 43.75 & 9 & 7 & 77.77 & 20 & 3 & 25,00 & 5 & 3 & 10.00 \\
\hline Anfurun & 18 & 9 & 50.00 & 7 & 3 & 42.85 & 20 & 6 & 30.00 & 5 & 3 & 60.00 & 14 & 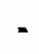 & - & 11 & 1 & 09.10 \\
\hline Winler & 23 & 10 & 41.66 & 2 & 1 & $\$ 0.00$ & 12 & 4 & 33.33 & 13 & 2 & 15.38 & $\nu$ & 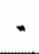 & $\sim$ & m & * & - \\
\hline Tolal & 77 & 38 & $49 \times 35$ & 23 & 12 & 51.17 & 64 & 27 & 42,18 & 36 & 20 & 55.55 & 45 & 6 & 13,00 & 30 & 4 & 13,33 \\
\hline
\end{tabular}

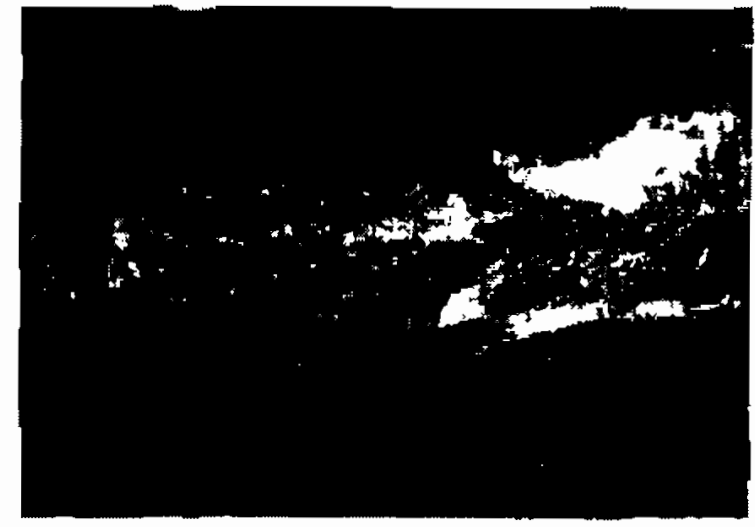

Figure (1): Showing Clarias garlepiress infested by large EMC in all musculature regions.

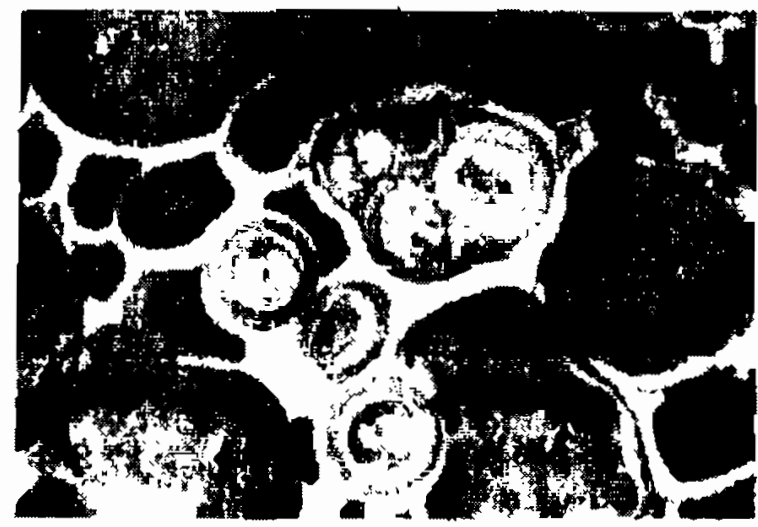

Figure (2): Shuwing Ovary of Oreachromis niloricus infested by Heterophyed avetacercariae. 
A

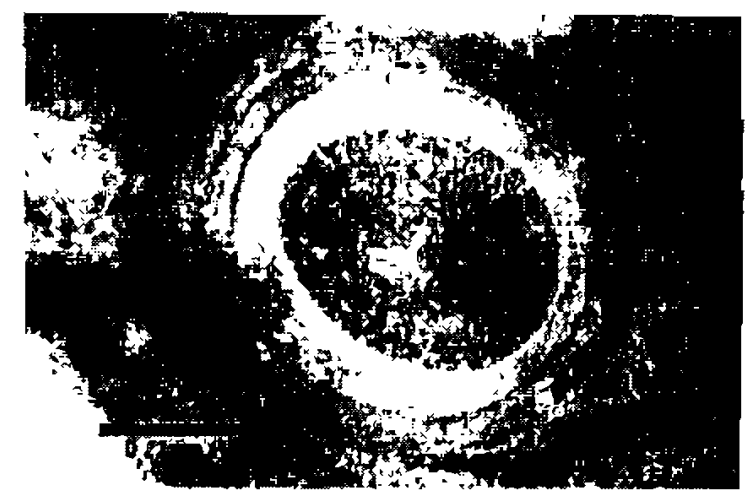

C

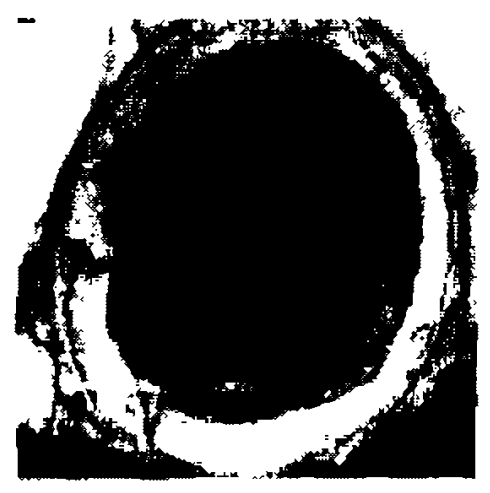

B

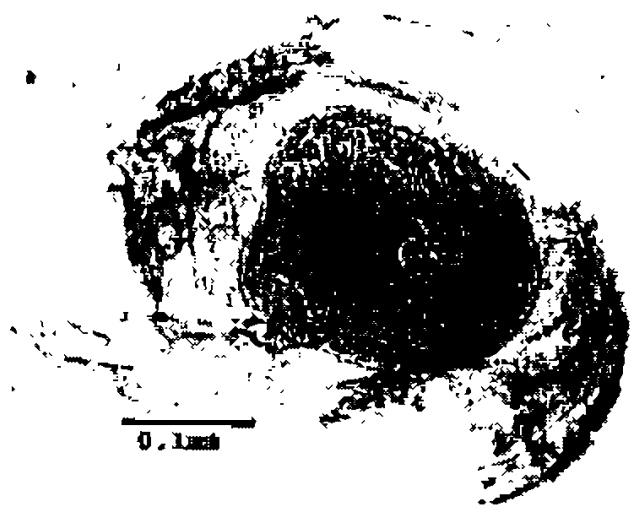

$\mathbf{E}$
D

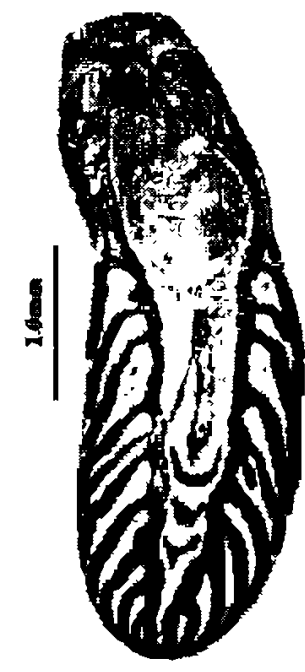

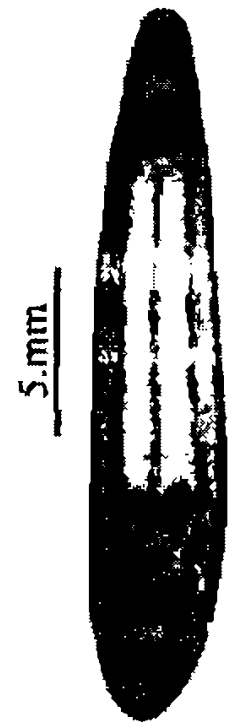

Plate (1) Showing metacercarea which isolated from $C$, gariepinus and $O$. niloticus A. Prohemistomatid, B. Heterophid C. Cynodiplastonatid D. Euclinostomum E. Cinostomatide metacercarea 


\section{REFERENCES}

Amany Abbsas (1097): Rule of Ish as an intermedlate host of some trematodes in birds. Ph.D. Thesis, Fac or Vet. Med. (Moshtohor), Zagazlg Unlv, Egypt.

Babatany. A. E. (200z) : Studles on the prevalling internal parasluc discases among some cultured freshwater ishes in Kair EdShelkh Province. M.V.SC. J. Fac. of Vet. Med. Tanta Univ.

Conray, D. A and Hermann. L. R. (1981) : Texibook of fish distases. T.F.ll. Publ. West Sylvanla.

Elasa, L. A M. (2002) : Parasltic ish diseases in Egypt. Dar E1-Nahdda El-Arabia Publushing Calro, Egypt. (2), P.(89).

Elesa, I. A M. and Haln, M. P. (1993); Studies on yellow grub disease in Nile Bolti. Beni-Suef, Vet. Med. Res., ul (1), 96-107.

Erasa, I. A M.; Dlad, A. S. and Badran, A. P. (1996) : Studies on some intemal parasiuc diseases among wild and eulturct $O$. niloticus flsh. 7 th Scl. Cong., Fac, of Vet. Med. Assult. 274-289.

Elasa; I. A. M.; Mona, M. A. Bherif; Hala, M. El-Geanddy and Aly, 8. 4. (2001) : Yellow gub disease amang Oreochromis nilut cus in relation to food quality and pathologlcal alterations. Suez Canal Vet.Med. IMI. J. N (2).

Floyd, R. F. (2009) : Introduction to nsh health management. Department of Asheries and aquatle sciences, Florida Cooperative extenslon service, institute of food and agricultural scicnces, University of Florida, circular 921 .

Kruse, G. O. W. and Pritchard, M. H. (1082) : The collection and preservation of anImal paraslles. Univ. of Nebjaska Press. Uniled States of Amertca.

Luckg, z. (1977) : Methods for the diagnosis of Msh diseases. Amer. Int. Publishing Com. PVT Ltd.. New York.

Maather Elamie. (2001): Studies on the diseases resulling from E.M.C. in same freshwater Ashes. M, V. Sc. Thes1s. (Fish Diseases and Mongement]. Facu. of Vet. Mediclne, Suez Canal University.

Morishlta, K.; Komlya, Y. und Maraubayshi, H. (1086) : Progress Medical Parasitology in Japan. Vol. II. Meguro Parasitologlcal Mu. seum. Tokyo.

Noor E1- Deen, A. 1. (2000): comparative studles on the prevalting parasitle diseases in monosex thapla and natural make ulaptas in kafr el-shelkh gov. Jish farms. Ph. $D$. Thesis of Vel. Med. Scl. Kafr Ed-Shelkh Unl.

Otrat Mahdy (1991) : Morpho-blological studies on the role of some Ireshwater nshes in transmitting parastlic helminihes of some avian hosts. Ph.D. Thesls. Fac. of Vet. Med. Cairo Unty.

Osman, A. H. (2001) : Studles on paraslte glll affections in some cultured freshwater 
Insines. M.V.Sc. Thesls. Facully ol Vel. Mediclne. Suez Canal University.

Rewle, Adawy (2000): Studies on the parasltuc diseases of some freshwater nshes in Dakahlla Gov. Ph. D. Degree of Vet, Scl. Fac. or Vet. Med. Calro Unlv.

Solah, Aly: Ismall, Elsga: Ahmed, Badran; Mauthor, Elarnle and Boushra HucseIn (2006): Pathologleai Studies on E.M.C. Infectons among Some Freshwater Fish in Egyptlan Aquaculture. Worldnsh Centre. Fish Health, Esypt

Semaha, H. I.: Y. M., Haggag and Nadla Mahfoux (2004) : Braeklsh and marine water nsh as a source of certaln baetertal pathogens to human beings. The $4^{\text {th }} \mathrm{Scl}$. Conference for Vet. Med. Researches Fae. Vet Med. Alex. Untv. 2-4 Oetober.

Bawran Eioheahnagui, Nablla, F. E. Sollman and Takwa, H, Esmall (2006) : PTevalence of nsh-borne parasite lil some fishes in Alexandrla, with special reference lo Anlsikis

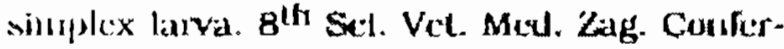
ence.

Shaapan, R. M. (1987) : Parasites of Ilshes and Its effect on public health. M.V.Sc. Thesls, Fac, of Vet. Med. . Cairo Univ.

Soulsby, E. J. (1982) : Helminths. Arthroprudes and Protozoa of domesticated antmals. $7^{\text {th }}$ ed. The English book soclety and Belluere. Tindall and London.

Taghreed, Ibrahlm, (2000) : Studles on metacercantal parasitle infestation in some Ircshwaler fishes M.V.Sc. Thesls, Cairo Unt., Egyjul.

Woo, P. T. K. (1996) : Fish diseases and disorderg Vol, 1 (protozoan and metazon Infectiong) CAB. Int. Wallingford. Oxan. UK.

Yamaguth. 8. (1968) : Systema Helminthum. Vol. I. Digenetic trematodes of vertebrates . Irart I \& II. Interscience Publishers. Ine. New York \& London. 